\title{
A systematic understanding of the evolution of Hindu deities in the development of the concept of avatara
}

\begin{abstract}
Within the primary and secondary Hindu scriptures, especially the Vedas, Epics and Puranas, many gods are mentioned. At times a hierarchy of deities is distinguishable, and at other times these deities assume each others' names and functions. Then there are some deities that manifest themselves in other forms such as a bird, an animal, a human, or both animal and human. These manifestations are at times clearly construed as avataras. To determine the transformation (metamorphosis), progression and/or regression of Hindu deities from the Vedas through to the Puranas, the researcher applied the systematic literature review methodology. He argued that this evolution of Hindu deities is the result of changes in the specific needs of the community in their quest for immortality. Accompanying this metamorphosis of Hindu deities is the notion of avatara which gained significant prominence in the Bhagavad Gita and the Puranas, although there are indications that the notion of avatara can be read into the Vedas. Considering these complexities, the researcher defined the term avatara and traced the origins and evolution of these Hindu deities through the various Hindu scriptures. This study consolidated this process systematically, resulting in sufficient proof that there was a decline in certain Vedic deities, a rise to prominence of other 'unimportant' deities and the appearance of other deities not mentioned in the Vedas.
\end{abstract}

\section{INTRODUCTION}

Religion seems to offer humankind a way to get closer to God so as to form a bond between God and humankind. It is the desire of humankind, who, knowing that they are mere mortals, strive for immortality, whether in this lifetime or within another sphere of life. In Hinduism this desire plays itself out on many fronts. This complexity of many fronts has led scholars to disagree on whether Hinduism is polytheistic, monotheistic, kathenotheistic or monistic.

Bassuk (1987:3) claims that in India, "ancient religious man connected God with animals which he revered and feared, so he attributed God-like qualities to these animals, creating theriomorphic deities". In support of this claim he cites just two examples from the Vedas amongst many other examples. The first example he cites was when the God Indra was manifested in the form of a bull or ram, and the second example was when the God Varuna comes out of the point of an arrow and becomes manifested as a bull. These manifestations, of which there are many in the primary as well as secondary scriptures of Hinduism, are at times construed as avataras.

Much has been written about avataras and their purpose for manifestations in different forms through the different epochs of the Hindu religion; yet a consolidation of these manifestations as recorded through the history of Hindu scriptures, the understanding of the concept of avataras and the reasons for the gods of the different Hindu scriptures seemingly undergoing metamorphosis, has yet to be systematically and comprehensively documented.

This article does not attempt to provide any new information which is not readily available. It 
is rather an attempt to construct a systematic review of literature, of both primary and secondary sources as well as references. This systematic review of literature provides the basis for a synopsis of the above-mentioned consolidation. Nonetheless, the focus is on why this metamorphosis of the Vedic gods took place, as well as the conception of Hindu deities in post-Vedic literature.

It is in the light of the above that a definition of the concept of avatara is considered in this article. Furthermore, an attempt is made to explain why there was a decline in the importance of the Vedic gods during the period between the Vedas and the Puranas. Finally, the rise to importance of the lesser gods from the Vedas, as documented in the secondary scriptures of Hinduism, especially in the epics and Puranas, is explained. The information contained herein provides the missionary with a clearer understanding on how the concept of avatara developed as against the Christian understanding of the incarnation. It should also settle the discussion that Jesus could not be the reincarnated Krishna.

\section{SCOPE OF LITERARY RESEARCH AND METHODOLOGY}

The literature available on the theme which this article focuses on is voluminous. The correct approach would be to address as many of these sources as possible. It stands to reason though that it is not possible to cover and/or engage many of these sources in an article. Such a task is best suited to a book for publication.

The researcher therefore had to confine the article to literature which defines the term avatara, addresses the reasons for the decline of the Vedic gods and explores the significance of the main gods in popular Hinduism arising from the epics and Puranas. The approach is twofold: firstly it is a systematic review of literature as explained above, and secondly it attempts to define the term avatara at the beginning of the article so as to place this term in perspective for the duration of the article. The reason for this approach is to impress upon the reader the importance of the concept of avataras throughout the article.

An attempt has also been made to avoid the use of terms in Sanskrit other than those words that are deemed necessary for the purpose of clarification in the context of the article. One of the main reasons for avoiding Sanskrit terms is the inability of the English language to render a justified explanation for these terms.

\section{TOWARDS A DEFINITION OF THE TERM AVATARA}

Miranda (1990:50) claims that the doctrine of avatara is indeed a characteristic feature of a theistic system of thought distinctive in Hinduism. It is a Sanskrit word which can be expressed in English as 'descent'. Pandey (1979:1) and Parrinder (1997:14) imply that the word avatara means 'to come down', 'to go down' or 'to descend'. Parrinder adds that avatara is the manifestation of the divine in human form. Burnett (1992:129) suggests that the etymology of the word avatara is from two root words, ava meaning 'down' and tr meaning 'to cross over'.

An investigation into the development of the term avatara is well postulated by Bassuk (1987:3). He suggests that Sanskrit terms used to describe the manifestation of the descent of God into the realm of this world evolved from rupa (form, figure), vapus (having a beautiful form) and tanu (a living entity who accepted a material body) to pradurbhava (appearance). He claims that the Sanskrit word avatara gradually evolved from these terms and that this word is composed of two parts: the root verb tr meaning to pass or cross and 'ava' signifying down. The finite verb avatarati means 'he descends'. Miranda (1990:50) refers to this descent as "the godhead's crossing over from the celestial regions down to the earth. It is the manifestation of the power of the deity. As a specifically religious term, it signifies both the 'descent' of the 
godhead from heaven and his 'appearance' in the form of animals (boar, fish, and tortoise), monster (man-lion), or men with superhuman and divine attributes."

In Sanskrit the variant of the verb avatara is the word avatarana, which is used to describe an actor making his appearance on the stage from behind the curtain just as the God-man manifests himself from heaven on the world stage. The word avatar became the Anglicised word of avatara. In Hindu philosophy an avatara is the ability of God to descend into the human world to address a specific problem. A clear indication of this is to be found in the Bhagavad Gita 4:7 where it states: "Whenever there is a decay of religion, O Bharata, and an ascendency of irreligion, then I manifest Myself." However, even in this instance the word avatara is not used as such.

One can therefore conclude that an avatara in Hinduism is the manifestation of God in the form of man or animal in this world so as to address a specific problem. These manifestations have taken many forms which are discussed more comprehensively in this article.

\section{ORIGIN AND EVOLUTION OF DEITIES IN HINDU MYTHOLOGY}

Although Miranda (1990:50) correctly claims that the term avatara is not used in the early works to signify the deity's descent on earth, there are a few references of the notion of avatars to be found in the minor Upanishads.

When one considers most of the works on Hindu scriptures, the earliest seminal concept of avatara is found within the Epics, especially the Mahabharata in that section known as the Bhagavad Gita. Even here in the Bhagavad Gita, according to Miranda (1990:50), other words are used to express avataras, such as 'birth', 'coming into being', 'creation', 'appearance', 'dwelling' and 'consorting with'.

The intention in investigating the origin and evolution of the Hindu deities and the eventual manifestations of these deities as avataras, is so that a fine thread can be weaved through the different periods of Hinduism indicating that, from the Vedic period through to the modern period, there is a link to avataras. In order to consider the evolution of the deities leading up to the manifestation of avataras, an attempt will be made to consider this investigation on three levels as indicated by Bhatt (2008:97): the decline and fall of the Vedic gods; the rise of certain Hindu deities in the epics; and the prominence of other deities in the Puranas.

\section{THE DECLINE AND FALL OF THE VEDIC GODS}

Flood (2005:44) maintains that the Vedic universe is populated with supernatural beings of various kinds. There is a divine being associated with every tree and river and some deities were afforded greater importance than others. According to Mitchell (2001:v) with regard to the Vedic deities, there are no convincing arguments to conclude that these deities were worshipped in the form of images because they were only visualised as having human or animal forms. He claims that "there remains the possibility that some of the lower strata of the population worshipped images in human or animal form and that this practice gradually spread upwards to the other sections of society. At a much later period, Vedic deities were retrospectively given human form and reproduced as images."

Mitchell (2001:vi) suggests that as the Aryans, the bearers of the Vedic religion, proceeded deeper into India, thus making contact with the local inhabitants, the old Vedic religion underwent several changes. Some deities changed their function while others gained or lost prestige.

Bhatt (2008:98) attributes the first reason for the decline in the Vedic gods to the fact that 
the important Vedic gods arose in order to meet specific conditions in the life of the Vedic people. When these conditions no longer existed, these gods faded into the background and new gods arose to meet new situations. Therefore one can conclude that no Vedic god could claim permanent supremacy. Wilkins (2008:13-14) cites the example where Dyaus and Prithivi are regarded as the parents of other gods, who made all creatures, conferred immortality on their offspring and were preservers of all creatures, yet they were superseded by Indra in the worship of the Hindus after their settlement in India.

Wilkins (2008:99) suggests that a second reason that could have contributed indirectly to the decline of the Vedic gods is evident in the Rig Veda Samhita. This is the rise of kathenotheism or henotheism. Within the Vedic pantheon there are as many as thirty gods among which Indra and Agni occupy the most prominent position. For the Vedic seer, the god from whom he seeks favour for the moment is the highest god. This attitude could have created an atmosphere of scepticism regarding the Vedic gods and could have adumbrated later Hindu sectarianism.

A third contribution to the decline of the Vedic gods is the rise of ritualism during the Brahamana period. Here the Vedic gods became subordinated to the institution of sacrifice. Ritualism could be said to have become a science in itself and grew more complicated. Bhatt (2008:101) remarks that "there was a gradual transfer of the potentiality from the gods to the more mechanical process by which they (the gods) were to be propitiated". In some instances the brahamic priests were more highly regarded than the Vedic gods themselves.

The fourth reason was the prominence of the Upanishads. Flood (2005:83) sees the Upanishads as the continuation of the Brahamanas in the interpretation of the rituals. However, he makes the distinction in this sense that there is an increasing importance of knowledge of esoteric correspondence in comparison to the rituals. This is to say that the sections on knowledge take precedence over rituals.

Here the search for the highest philosophical truth became the point of focus. Parrinder (1975:95-96) says that "[i]n the Upanishads there is a deeper search for the heart of reality". He quotes Dasgupta as saying that "this quest is not the quest of the God of the theists" but "the ultimate essence of our self". In this regard Bhatt (2008:101) states that the Upanishadic thinkers "sought to understand the reality that underlies Vedic gods and Vedic ritual, which after all were mere external and temporary manifestations of that reality". Maxwell and Naidoo (1991:51) consider the Upanishads as a "movement towards unity (there is one divine reality); a movement towards subjectivity or inwardness (the divine reality is within you); and a movement towards spirituality (the emphasis on inner realisation rather than external rituals)". Patton (2004:48) claims that some scholars call this process "the internalization of the sacrifice" and that it was not a rejection of the sacrifice mentioned earlier.

This idea of the movement towards unity and 'internalization' is evident in the Brahadaranyaka Upanishad III.ix. 1-9 where Sakalya pressured Yajnavalkya to state how many gods there are. Through the process of reduction from 3306 gods, Yajnavalkya concluded that there is only one. This reduction obviously further suggested the decline of the prominence of the Vedic gods. In this regard Patton (2004:48) asks what has become of the Vedic deities and answers this by saying:

"Many of the deities are still quite active and involved-such as Indra, who is engaged in much questioning and dialogue throughout most of both the earlier and later Upanishadic texts. However, while the activity of sacrifice is still presumed, the Upanishads use the deities themselves as aids to a certain kind of knowledge ... The object of that knowledge is no longer the gods per se but the new force called Brahman."

This idea of Brahman began to gain momentum in the Upanishads and it seemed that it was only well understood by those of great intellect (knowledge) and therefore could not be regarded 
as 'popular religion'. Here the movement from a plethora of gods to a single 'force' known as Brahman began to evolve more fully.

In the later Upanishads theistic ideas began to recur. Bhatt (2008:102) suggests that this is an indication of sectarianism but essentially only with reference to Hindu gods like Shiva and Vishnu, rather than with regard to the Vedic gods like Indra and Varuna. This, he says, is the result of the "Hinduisation of the Upanishadic thought" (2008:102). It is in the Svetasvatara Upanishad where this thought of "Hinduisation of the Upanishads" is conceived. There, ideas of monism and monotheism are blended and Rudra is identified with Brahman. This transfer of the attributes of the Upanishadic Brahman to a personal god substantially helped in enhancing the popularity of Rudra and Vishnu, who were minor deities in the Vedas (Bhatt, 2008:102). With the development and philosophy of the Upanishads and in the course of its evolution, it could be presumed that the Vedas became mythological and ritualistically hieratic as in the Samhitas and Brahamanas, or, in the case of the Upanishads, intellectually abstract.

Flood (2005:103) contends that from about 500 before the Common Era there was a growth of sectarian worship of particular deities. Even though Vedic sacrifice still existed, there was a movement towards the devotional worship of a deity. This practice of devotional worship (bhakti) became the religious practice of Hinduism. This movement and its growth are reflected in the epics, and in the mythological and ritual treatises known as the Puranas.

The following section traces the development of the Epics and the Puranas, with special attention to the rise of the gods Vishnu, Shiva and Brahma culminating in their manifestations as avataras. These three gods collectively came to be known as the tri-murti (three gods or 'trinity'). It will also be possible to trace the genealogy of these gods up to the Vedic period. It is important to mention that of these three gods, Vishnu and Shiva were prominent and gained a large following among Hindu devotees. Brahman seems to have been confined to the shadow of Vishnu and Shiva.

\section{CONCEPTION OF HINDU DEITIES IN POST-VEDIC PERIODS}

Chennakesavan (1980:43) claims that the "process of clothing the abstract Brahman of the Upanishads with flesh and blood and making it into a personality ... gains momentum in the Epic Age and becomes almost a solid theory of Personalism". It seems obvious that in making this claim Chennakesavan is referring to the Mahabharata epic, especially that portion referred to as the Bhagavad Gita. This will be discussed more fully later in this article.

Mitchell (2001:vi) asserts that in the further development of Hindu deities, it is in the Puranas that a compendium "of all that was known about the gods contained in the Vedas and Epics, linking the gods by elaborate genealogies, providing religious instructions, and inserting many interpolations" are contained. He claims that as a consequence of this, subsequent deities emerged as a result of the formalisation as found in the Puranas. In the following quotation from Bhatt (2008:104), which best sums up the position thus far with regard to the declination of the Vedic deities, he lends support to the theory that the change in the specific needs of the community in their quest for immortality necessitated a change in the way the common Vedic gods were venerated:

"Therefore, in an atmosphere which was still imbued, to a greater or lesser degree, with Vedism, Hinduism did not stand out as something alien. At the same time, Hinduism, which arose essentially as a popular religion, could not acquiesce in the ritual of Vedic religion as such. It, no doubt, accepted Vedic gods, but assigned to them a subordinate position. Vedic gods, like Indra and Varuna, gave place to the popular gods like Vishnu and Shiva; Vedic ritual was generally superseded by bhakti, tapas, yoga and samnyasa. This is the religious 
background of the Epics and the Puranas."

The contribution of the Epics and the Puranas, which were regarded as popular religion and more vastly read and understood by the common believer in Hinduism, has been considered in the conceptualisation of Hindu deities. This period sees the composition of the Ramayana and the Mahabharata, known as the Epics as well as the bulk of the Puranas. This period is also regarded as the transitional period in Hinduism (Rodrigues: 2006:136).

\section{THE EPICS}

The Ramayana and the Mahabharata are two important epics in Hinduism. Both these epics focus on the deity Vishnu, especially in his manifestation as Rama (of the Ramayana epic) and Krishna (of the Mahabharata epic). Although emphasis is placed on these two deities, other deities of lesser significance, and which are largely those of the Vedic pantheon, are also alluded to in the epics (Brockington, 2003:116). Since the nature of the epics is conceived of as a specific literary genre, and for the purpose of discussing the evolution of the deities in this context, a deliberate focus is placed on an allegorical interpretation. It is correct to state that embedded in these epic texts there is much philosophy and religion which also serve as guidelines for an ethical lifestyle. This is once again an indication of a change in attitude towards the gods of the Vedas in the Hindus' quest for immortality in this life or the next. Attention is given to the Ramayana first as it is understood to be the older of the two known epics.

\section{THE RAMAYANA EPIC}

Although Chennakesavan (1980:44) says that the Ramayana is not philosophically important and that it can be regarded as an 'ethical treatise', there does emerge an allegorical theistic interpretation to which Prime (1997:7) alludes:

"Rama is God incarnate, the seventh incarnation of Vishnu. [...] He suffered physical hardships, and [...] a broken heart. [...] Rama's journey is an allegory for the journey every soul must make. In becoming human Rama shared in our human suffering and enacted the drama of our lives. [...] Thus to hear or to witness Rama's struggles is to relive our own lives, but in a divine context. Each episode in the story is multi-layered, working through individual karma, or destiny, and the divine lila, or play, of Rama."

Even Rosen (2006:68), although admitting to different regional variants in local dialects of the Ramayana, summarises the essence of this epic with an exegetical slant by stating that:

“... the Supreme Lord appeared on earth as a human prince named Ramachandra. [...] a group of demigods approaches Lord Brahma, their leader, with concerns about a demon king, Ravana [...] Because of the demon's austerities, Brahma had given him a boon [...] saying that he "could never be defeated in battle, not by god or by any heavenly creature". [...] However, Brahma's blessings did not mention humans, leaving open the possibility that a highly qualified human, someone more powerful than any other heavenly being or demigod [..] could perchance conquer him [...] At that moment, Lord Vishnu descended, and He assured them that He Himself would incarnate as a human being named Ramachandra [...] By incarnating as a human, Rama not only enabled himself to defeat the demon-king but also set an ideal example for human behaviour."

In both of the above interpretations, the god Vishnu is significant as the incarnated Rama. Brahma is also significant as he appears to be the leader of the demigods. At the end of the main Ramayana narrative it is Brahma who leads the assembly of the gods in order to reveal his divinity to Rama. Bassuk (1987:31) also mentions the god Shiva together with Brahma, whom 
Ravana wanted to propitiate. Rosen (2006:69) refers to Vishnu as the Supreme Lord. These three gods, Vishnu, Shiva and Brahma, are also mentioned in the Vedas, but hold a minor position in the pantheon, yet gained prominence in the epics and Puranas, as will be discussed later. From this rendering, glimpses of the concept of avatara begin to emerge. Other Vedic gods are also mentioned in this epic. Brockington (2003:118) claims that Rama is often compared to Indra and, with his duel with Ravana, receives the help of Indra's charioteer, Matali. The deity Agni also plays an appreciative role in returning Sita to Rama after Sita passed through the fire in order to prove her purity.

\section{THE MAHABHARATA EPIC}

The Mahabharata was chiefly concerned with the control of the Kuru kingdom between two sets of cousins. This situation eventually led to open warfare. Many modern scholars regard the Mahabharata as an exploration of the problems involved in establishing the nature of dharma. This is vividly expressed when the Pandavas returned from exile to a hostile Kauravas who refused to settle an agreement made before the Pandavas were sent into exile. Rosen (2006:86) says that the ensuing war did not only include the armies, but also involved gods, even Krishna, the manifestation of the Supreme Being.

In light of the Mahabharata and its continued war, Chennakesavan (1980:45) could state that "what was initially a heroic poem becomes a Brahmanical work, and is transformed into a theistic treatise in which Vishnu and Shiva is elevated to the rank of the Supreme" and "in the course of time, a theistic authority". The clearest revelation of the nature of God is to be found in the Bhagavad Gita, a small book which emerges from the voluminous Mahabharata. In it an intense conversation ensues when Krishna appears as a charioteer to the warrior Arjuna of the Pandavas family. Rodrigues (2006:148) points out that prior to this event Krishna was a family friend to both the Pandavas and the Kauravas. When his help was sought in the battle, Krishna offered his army to the Kauravas and himself as a non-combatant adviser to the Pandavas. The Bhagavad Gita centres on the deep conversation between Arjuna and Krishna while still in the battlefield. Arjuna had serious doubts about going to war with his cousins. It is here that Krishna answers Arjuna's many questions and resolves his doubts about going to war with his cousins. It is in the Bhagavad Gita 4:7-8 that Krishna reveals his true nature when he says, "Whenever there is a decay of religion, $\mathrm{O}$ Bharata, and an ascendency of irreligion, then I manifest myself [...] Age after age I come into being." Parrinder (1997:37) suggests that this is the clearest statement of the avatara doctrine in the Bhagavad Gita. There are other references to this effect in the Bhagavad Gita in 7:24 and 9:11. He does concede that although the word avatara does not occur per se, yet the doctrine of avatara is evident. However, Parrinder (1975:39) notes that Krishna was possibly an ancient Indian non-Aryan divinity and as a result was popular with the people. In the Bhagavad Gita Krishna now appears as an avatara (descent, 'incarnation') of the Vedic god Vishnu.

Throughout this epic, in a similar vein as the Ramayana, the deities alluded to find their origin in the Vedic literature. One example is the god Indra, who serves as both leader of the gods and as a performer of heroic deeds. The five Pandavas were fathered by the gods, an example being Indra, father of Arjuna, and Yudhishthira, the eldest son, who was born of the God of Right (Dharma) (Parrinder: 1997:21); Yama is prominent among the boastings of the warriors; Agni plays an appreciable role in the narrative of the Mahabharata and in the allusions made to Shiva and Vishnu which find their source in the Vedic literature. Once again the fine thread of the evolution of the deities is visible as it weaves through the Vedic literature to the epics. What is observed, though, is an erosion of the importance of the Vedic deities during this 
process of evolution.

The Mahabharata is followed immediately by another genre of literature known as the Puranas. Here the gods and goddesses which were encountered in the Epics become the focus of attention. The result of this is a more significant fading away of the importance of the Vedic deities. Nonetheless, the thread continues to weave through to the Puranas.

\section{THE PURANAS}

The Puranas, of which there are many, constituted an oral tradition that was written down. They were influenced by the Epics, Upanishads, Dharma literature and ritual codes. Rodrigues (2006:188) states that the "foremost concern of the Puranas is to align the world-view of Vedic Hinduism with rapidly expanding bhakti theism". Together with bhakti theism, these Puranas were also concerned with the creation of the world, destruction and recreation, the world periods and the deeds of heroes and genealogies of individual gods and kings. This gave prominence to a particular deity as the Supreme Being and the use of an abundance of religious and philosophical concepts (Shattuck, 1999:43). Rosen (2006:139) suggests that the "Puranic texts unabashedly present the Hindu deities in full, with elaborate detail and theology".

There are 18 great Puranas (Mahapuranas), which are considered scripture by most Hindus, and many lesser Puranas (Upapuranas), which wielded regional authority.

Flood (2005: 110) says that the Mahapuranas are classified according to three gunas (qualities): sattva (purity or quality of light), rajas (passion) and tamas (inertia or darkness). There are six Puranas to be found in each category: the sattva category contains the Vaishnava Puranas with Vishnu as the central deity; the rajas category contains the Brahma Puranas with Brahma as the central deity; the tamas category contains the Shaiva Puranas with Shiva as the central deity. These classifications form three sets of six books each. According to Rosen (2006:141), each of these sets is associated with one of the main gods of India - Brahma, Vishnu or Shiva - as alluded to earlier.

For the purposes of this article, and for the conclusion in substantiation of the origin and evolution of Hindu deities in their manifestations as avataras, due consideration is given to the Mahapuranas because in them is found the essence of contemporary Hinduism.

Flood (2005:110) contends that the Puranas contain essential material for understanding the religions of Vishnu, Shiva, Brahma, Devi, Agni (god of fire), Skanda (god of war and son of Shiva) and Ganesha (Shiva's elephant-headed son). These Puranas establish the rise and popularity especially of Vishnu and Shiva, two of the gods that were encountered in the earlier writings of Hinduism. According to Rao (2009:9), Brahman received worship until the ninth century together with the other two gods. Later however, the votaries of Brahman diminished in number and importance and there were few independent shrines to Brahman. Rosen (2006:142) acknowledges that all Puranas extol the virtues of Vishnu and Shiva, but very few refer to Brahma as deity. Of these three gods Vishnu alone has avataras. Shiva has offspring such as Ganesh, but no avataras, and Brahma ceased to have any importance, as mentioned earlier. Against this background, the two more prominent gods in the Puranas, Shiva and Vishnu, are subsequently discussed.

\section{SHIVA}

With the discovery of the 'Proto-Siva Seal', at Mohenjodaro in the Indus Valley, and with the renderings in the Puranas, one can see the resemblance and close connections with this seal and the characteristics of Shiva depicted in the Puranas, especially with regard to the yogic positions 
in both these renderings. The name 'Shiva' is not mentioned in the Vedas and this could be because it was not a god venerated by the Aryans. Wilkins (2008:263) suggests that in order for Shiva to gain prominence and to receive greater reverence, he was declared to be Rudra of the Vedas. The earliest reference to Rudra is found in the Rig Veda, although a very minor position is assigned to him. There are only three full hymns addressed to him. Nonetheless, a clear picture emerges of him where he is mentioned seventy times in total.

Wilkens (2008:265) further suggests that Rudra did not remain a subordinated deity as in the Vedic age, but threw "Agni, Vayu, Surya, Mitra and Varuna completely into the shade" and that together with Vishnu "engrosses the almost exclusive worship of the Brahmanical world". Lipner (1994: 283-4) suggests that on the basis of the Svetasvatara Upanishad which exalts Shiva, it could be conjectured that he was a monotheistic cult deity and in time became the "assimilative centre of a vast and many-faceted mythic tradition".

With regard to earlier references to Shiva, Patanjali's 'Great Commentary' on Panini's Sanskrit grammar, a devotee of Shiva is described as clad in animal skin and carrying an iron lance as a symbol of his god, a possible precursor of Shiva's trident. Even Bhandarkar (1983:165) claims that there are Shaiva Ascetics in the Mahabharata. Yet it is only in the Puranas that Shiva is really exalted and developed as a major god in Hinduism. He assumes many forms but never as an avatara.

\section{VISHNU}

In the Rig Veda Vishnu is the benevolent, solar deity associated with Indra, often in fighting the demon Vrita. In one hymn Vishnu takes three giant strides across the universe, the three realms of earth, air and heaven. In this way he seems to be declared 'the preserver' in the Vedas. This forms the basis of a myth in the Puranas where Vishnu is incarnated as a dwarf, covers the earth in three strides and destroys the power of the demon Bali.

In the Vedas and the Upanishads Vishnu is not significantly prominent, but only in the Epics does he become pre-eminent. Rosen (2006:152) comments that although Vedic references to Vishnu are few, yet they are overflowing with meaning.

In the Rig Veda Vishnu is a "good friend of the good folk" $(1,154,4)$ and a "compassionate protector" $(3,55,10)$. Satapatha-brahamana $(3,7,1,17)$ explores an intimate association of Vishnu with Sun and in the Rig Veda $(2,1,3)$ with Agni. According to Rao (2009:14), it has also been suggested, that during the Vedic times there were iconic representations of Vishnu. Mishra (2000:21), in examining the origin of incarnation in Indian mythology, says that the theory of incarnation is connected with Vishnu. Bassuk (1987:23) suggests that the unnamed descents of Vishnu developed into various accounts of avataras as found in the epics, the Puranas and the Brahamanas. He further claims that in the Mahabharata there are three lists of Vishnu's incarnations but that they are inconsistent. First, four avataras are mentioned, then, two more are added and finally a list of ten avataras is mentioned. Parrinder (1997:16) proposes that, "with his avatars, perhaps incorporating Indus Valley or forest divinities, Vishnu emerges as the deity who is to this day the greatest or sole god to millions of Hindus".

The main lore about the avataras of Vishnu is to be found in the Bhagavata Purana, which is sometimes referred to as the 'Fifth Veda'. Other Puranas also list a number of avataras, though of course the Ramayana and the Mahabharata are critical sources for the two heroic avataras of Vishnu, namely Rama and Krishna. Yesurathnum (1987:46) claims that from the Bhagavata Purana it is understood that the number of avataras may be endless. In the Bhagavata Purana (1.3.26-27) it is stated that, "[j]ust as from an inexhaustible lake thousands of streams flow on all sides, so also from the Remover-of-Sorrows (Hari), sum of all reality, come forth countless 
incarnations". In the following section the number of avataras of Vishnu is examined more closely.

\section{AVATARAS OF VISHNU}

Although the Bhagavata Purana claims that there are innumerable avataras, there seems to be an inconsistency regarding the number of avataras within it. A closer examination of the number avataras in the Bhagavata Purana reveals that at one place twenty-two avataras are enumerated, while at another twenty-three and yet at another only sixteen are listed. The Varaha Purana records ten avataras and the Sattvata Samhita and Ahirbudhnya Samhita thirty-nine avataras. The Matsya Purana explains that Vishnu had to appear seven times among human beings, in order to expiate the sins of the wicked rulers. The Vayu Purana speaks of ten avataras of which three are regarded as celestial and other terrestrial. Although the Garuda Purana alludes to innumerable avataras, it lists only nineteen. According to Bassuk (1987:23) and verified by Rao (2009: 20), although there is a variance in the number of avataras there are only ten major or principle avataras that have been widely accepted. These ten avataras are:

- Matsya (The Fish)

- Kurma (The Tortoise)

- Varaha (The Boar)

- Narasimha (The Man-Lion)

- Vamana (The Dwarf)

- Parasurama (Rama with the Axe)

- Rama (Son of Dasaratha)

- Krishna (Yadava Prince)

- Buddha (Prince of Sakyas)

- Kalki (The Apocalyptic Avatar)

Each of these avatars played a significant role in addressing one or other problem on earth. It is not possible in this article to discuss what these problems were and how they were resolved, but it would suffice to state that there was certainly a greater involvement of god as an avatar in the affairs of humankind.

\section{CONCLUSION}

In the opening statement of this article, it is stated that religion was the tool humankind could use to form a bond between God and humankind. The systematic literature review methodology was used to trace the evolution of Hindu deities through the rich collection of Hindu writings and scriptures. It was not possible to include every Hindu writing or scripture because of the vast volume that is available, but a gleaning of these texts has allowed for sufficient information to postulate the firm belief and faith in the Hindu idea of avataras. The decline of many Hindu deities has been studied through this research while the rise to prominence of some deities to pre-eminence was explained; culminating in the concept of avataras, which now forms the belief system of popular Hinduism. In tracing the transformation (metamorphosis), progression and/or regression of Hindu deities from the Vedas through to the Puranas, the conclusion is that this evolution of Hindu deities not only conformed to the changes in the specific needs of the community in their quest for immortality, but also allowed for the deep philosophical thought espoused by the many scriptures and god(s) in Hinduism to be more accessible and personal to the common people of simple beliefs.

This research also proved that gods that were prominent in the Vedas either vanished 
altogether or, in the case of the less important gods, gained recognition even to the extent of becoming the main focus of worship for the Hindu. It was furthermore proven that the secondary scriptures contributed to either the demise of Vedic gods, or to the elevation of other gods such as Siva and Vishnu. Finally, for the Hindu believer, religion can indeed offer humankind the possibility of striving for immortality either in this life or the next. For the Christian believer immortal life is only through the incarnated Christ, who is the only begotten Son of God.

\section{BIBLIOGRAPHY}

Bassuk, ED. 1987. Incarnation in Hinduism and Christianity. The Myth of the God-Man. London: Macmillan Press

Bhandarkar, RG. 1983. Vaishnavism, Shaivism and Minor Religious Systems. New Delhi: Asian Educational Services

Bhatt, NR. 2008. Shaivism in the light of Epics, Puranas and Agamas. Varanasi: Indica Books

Brockington, J. 2003. The Sanskrit Epics, in Flood 2003:116-128

Burnett, G D. 1992. The Spirit of Hinduism. A Christian Perspective on Hindu Thought. Tunbridge Wells: Monarch

Chennakesavan, S. 1980. A Critical Study of Hinduism. Delhi: South Asia Books

De Gruchy, WJ, Prozesky, M (eds). 1991. A South African Guide to World Religions. Cape Town: David Phillip Flood, G. 2005. An Introduction to Hinduism. Cambridge: University Press

Lipner, J. 1994. Hindus. Their Religious Beliefs and Practices. New York: Routledge

Maxwell, P \& Naidoo, T. 1991. The Religions of India, in De Gruchy and Prozesky 1991:43-83

Miranda, P. 1990. Avatar and Incarnation. A Comparative Analysis. (From Dr. S. Radhakrishnan's Viewpoint). New Delhi: Harman Publishing House

Mishra, R. 2000. Theory of incarnation. Its Origin and Development in the Light of Vedic and Puranic References. Delhi: Pratibha Prakashan

Mitchell, A G. 2001. Hindu God and Goddesses. Delhi: UBSPD

Mittal, S, Thursby, G (eds). 2004. The Hindu World. New York: Routledge (Paperback 2007)

Pandey, R K. 1979. The Concept of Avatars (With Special Reference to Gita). Delhi: B.R. Publishing Corporation

Parrinder, G. 1975. Upanishads Gita and Bible. A Comparative study of Hindu and Christian Scriptures. London: Sheldon Press

Parrinder, G. 1997. Avatar and Incarnation. The Divine in Human Form in the World's Religions. Oxford: One World

Patton, L. 2004. Veda and Upanishad in Mittal and Thursby 2004:37-51

Prime, R. 1997. Ramayana: A Journey. London: Collins and Brown Ltd.

Rao, R S K. 2009. Visnu Kosha. Delhi: Sri Satguru Publications

Rodrigues, P H. 2006. Introducing Hinduism. New York: Routledge

Rosen, J S. 2006. Essential Hinduism. Westport: Praeger

Shattuck, C. 1999. Hinduism. London: Routledge

Wilkins, W J. 2008. Hindu Mythology. Vedic and Puranic. New Delhi: Rupna and Co.

Yesurathnam, R. 1987. "The Mythic Symbol Avatara in Indian Conceptual Formulations". Dialogue and Alliance. 1 No 2 Summer 1987 pp 3-12

\section{KEYWORDS}

Hinduism

Avatara

Deities

\section{TREFWOORDE}

Hindoeïsme

Avatara

Gode
Maniraj Sukdaven

Head - Department of Religion

Studies

Faculty of Theology

University of the Free State

Tel: 0514013272

Faks: 0514013508

Cell: 0828223851

E-mail: sukdavenm@ufs.ac.za 